\title{
流動化コンクリート長距離圧送による 橋りょう床版の暑中施工
}

加藤三樹夫 $*^{1} \cdot$ 久米井 隆 $*^{2} \cdot$ 梅 原 秀 哲*3 $・$ 吉 田 弥 智*4

\begin{abstract}
概 要 名古屋市道高速一号万場大橋は, 都市高速道路として 1 級河川庄内川に架設される 3 径間連続非合成箱げた橋であ る。本工事の床版コンクリート打設は, 暑中施工となり, また現場条件が河川上であることからポンプ圧送距離が大となる(換 算水平長 $360 \mathrm{~m}$ ) ので, これらの施工性改善のため, 後添加方式の流動化コンクリートを採用したものである。本稿は, 橋り ょう床版の流動化コンクリートの施工について述べる。

キーワード : 橋りょら床版の施工, 流動化コンクリートの暑中施工, 後添加方式, 長距離ポンプ圧送
\end{abstract}

1.まえがき

本橋りょうは，図一1 に示すように名古屋西部に位置 し, 県道中一色一名古屋線（通称, 万場大橋線）の交通 の要所として知られる万場大橋 (1 級河川庄内川) 上に 都市高速一号として架設される，橋長 $196.8 \mathrm{~m}$ の 3 径間 連続非合成箱げた橋である。

このため，本橋りょうの床版工事にあたり，万場大橋 線上の交通(日交通量 2 万 7000 台)を阻害しない施工方 法を選定しなければならなかった。とくに床版コンクリ 一ト打設時に，ポンプ車を所定の位置に配置するスペー スの確保が困難であった。そこで，近年急速に使用が増 えている流動化剤を使用することにより，暑中における ポンプ圧送性を改善して長距離圧送することを計画し， 種々の予備試験を行って本施工を実施した。本稿は，流
動化コンクリートの長距離圧送による床版コンクリート の暑中施工について報告するものである。

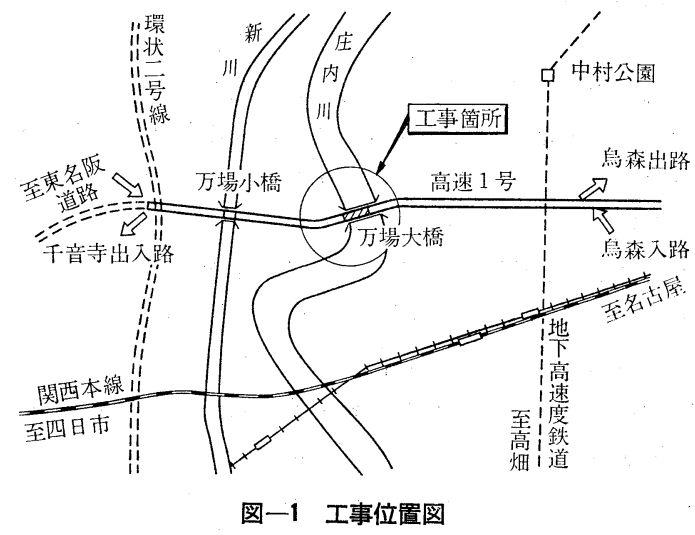

側 面 図
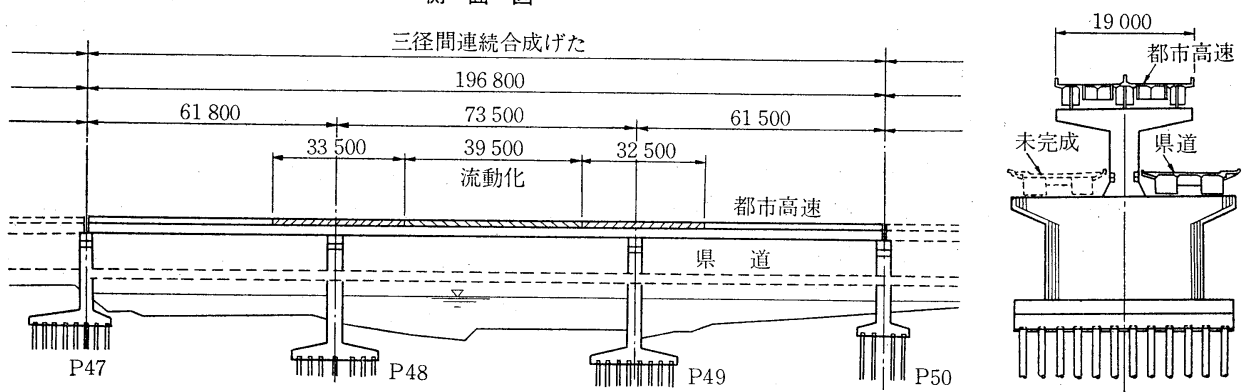

図一2 概 要

*1 正会員 名古屋高速道路公社工務部

$* 2$ 新井組 (株) 名古屋支店
*3 正会員 名古屋工業大学講師 土木工学科

*4 正会員 名古屋工業大学教授 土木工学科 


\section{2. 工 事 概 要}

本工事の概要は 図一2に示すとおりで, 詳細は下記の とおりである。

\section{(1) 工事名称等}

路 線 名: 市道高速一号

工. 事 名：万場大橋（その1）工区床版工事

工事場所：名古屋市中川区富田町大字万場字北畑東 発 注 者: 名古屋高速道路公社:

施工時期：昭和 58 年 8 月下们（床版施工時）

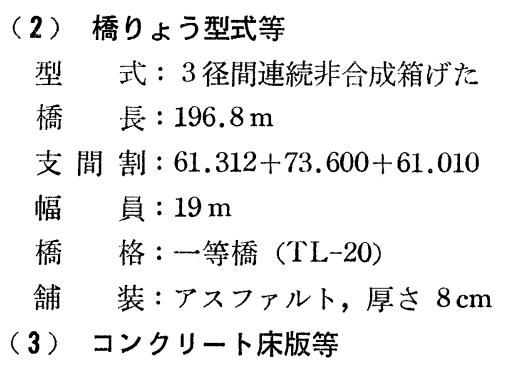

床 版 : 鉄筋コンクリート, 厚さ $20 \mathrm{~cm}$

打設数量 : $825.8 \mathrm{~m}^{3}$ (流動化コンクリート $436.3 \mathrm{~m}^{3}$ )

配 合 : 270-8-25

流動化剂 : パリック FL

\section{3. 流動化コンクリートの採用}

本橋りょうの立地条件は, 橋長 $196.8 \mathrm{~m}$ のうち大部 分が水上部となっており, 平面街路の万場大橋と並行し ている。しかし万場大橋では, 上流側の 2 車線道路の架 設工事を名古屋市が行っており, 下流側の 2 車線道路が 供用されているため, 大橋上を交通阻害のないよう施工. しなければならなかった。このため，コンクリート打設 時にはポンプ車を隣接橋りょう（橋軸方向）部に設置し なければならないため, 長距離（水平最大 $260 \mathrm{~m}$, 鉛值 $14 \mathrm{~m}$ ) 圧送が必要となった。また, 1 日当りの打設数量 は，連続げたのため打設区画をすると $250 \mathrm{~m}^{3}$ になり， さらに打設時期が夏季で, その高温下においてスランプ
$(8 \mathrm{~cm})$ の低下によるポンプ閉そくが奬念された。この ため, 所要の品質を確保した状態で施工性（ポンプ圧送 性, 打込み・締固めやすさ）を改善することにより所定 の打設量を達すべき方法を検討した。この結果, 近年着 目され始め，施工実績も増えつつあり，「流動化コンク リート施工指針（案）」（土木学会）も確立された，後添 加方式高性能減水剂を用いた流動化コンクリートを採用 した。

\section{4. 施 工: 概 要}

施工計画の段階で, 種々の打設方法（生コンクリート のトロッコによる運搬, ポンプ車および定置式ポンプに よる 2 段階運搬等）の調查・検討を行った。その結果， 過去の実績もふまえて品質管理, 施工管理, 採算性を考 え, 現時点での最善の施工方法を採用した。施工の概要 を図一3 に示す。

5. 流動化コンクリートの予備試験

\section{1 室内 試 験}

\section{(1) スランプの選定}

ポンパビリチーの改善を目的とするため, 流動化コン クリートのスランプを決定した。まず最初に, 流動化コ

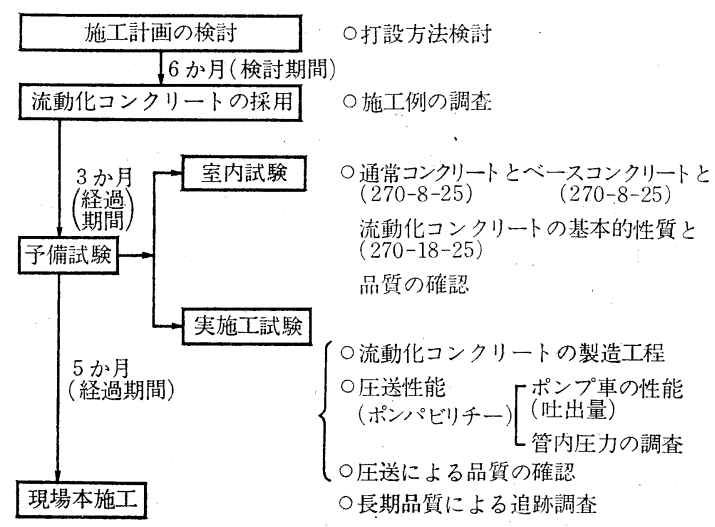

図一3 施 工 概 要

\section{Construction of Bridge Slab in Hot Weather by Use of Superplasticized Concrete Pumped in Long Distance}

By M. Katoh, T. Kumei, H. Umehara and H. Yoshida

Concrete Journal, Vol. 22, No. 9, pp. 48 55, Sept. 1984

Synopsis Manba-Ohashi in the First Municipal Highway has been constructed as a three-spans continuous box girder bridge over the Shonai River. As placing of slab concrete in this bridge was conducted during hot weather and working bield was over the river, superplasticized concrete pumped in long distance was used. This paper presents the details of the construction of this bridge slab.

Key words : construction of bridge slab, superplasticized concrete in hot weather, delayed addition, long distance pumping 
ンクリートのポンプ筒先のスランプを目標 $10 \mathrm{~cm}$ とし, 長距離圧送をするための運搬時間の延長に伴うスランプ ロスを $8 \mathrm{~cm}$ と仮定した。その結果, 流動化コンクリー トのスランプは $18 \mathrm{~cm}$ と決定された。一方, 基本となる ベースコンクリートのスランプが, 床版コンクリートで は公社基準值が $8 \pm 2.5 \mathrm{~cm}$ と決まっているため, スラン プ増大量としては $10 \mathrm{~cm}$ となった。

\section{（2）使用材料およひ配合の決定}

使用するコンクリート材料を 表一1 に示す。通常, ベ 一ス, 流動化各コンクリートの配合の比較を 表一2 に示 す。以上による試し練りを名古屋工業大学士木材料実験 室で行い, 流動化剂を用いた場合の流動化効果, 空気連 行性と圧縮強度について比較, 確認を行った。配合決定 としては, ベースコンクリートは, 通常コンクリートの 配合を $W / C=50 \%$, スランプ $8 \mathrm{~cm}$, 空気量 $4.5 \%$ （流 動化剂は空気量を若干減少させる傾向がある) と選定し, 流動化コンクリートはスランプ $18 \mathrm{~cm}$, 空気量 $4.0 \%$ と 決定した。また, 細骨材率 $(s / a)$ については, スランプ $18 \mathrm{~cm}$ の通常コンクリートでは $42.4 \%$ を用いているが, 同ビスランプの流動化コンクリートではやや分離傾向が 認められたので， $43.4 \%$ と $1 \%$ 増加して材料分離を防 いだ。

\section{(3) 結果と考察}

1）フレッシュコンクリートの基本的性質一 ベース コンクリートの練りまぜには可傾式ミキサ（容量 $80 l$ ) を使用した。練上り直後にスランプ, 空気量, コンクリ 一ト温度を測定し, その後 10 分間放置後, 流動化剂を 添加して 1 分間擋拌し，その直後 に流動化コンクリートのスラン プ, 空気量, 温度を測定した。以 後, 15 分ごとに 1 分間擋拌を繰り 返し，そのつどスランプロスを測 定した。その結果, スランプにつ いては, 添加後約 45 分でベース コンクリートのスランプに戻るこ とが認められた。気温 $25^{\circ} \mathrm{C}$ 以上 では 45 分が限度と考えられる。 また，添加時期が遅いほど，経時
によるスランプロスが大きいことを考虑すれば，練上り 後約 55 分以内に打設を完了すべきと思われる。空気量 については, ベースコンクリートを $4.5 \%$ としたことに より, ベースコンクリートの練上り時点, 流動化肪添加 擋拌時点, およびスランプがベースのスランプと同じに なった時点（スランプ復元時）の 3 ケースとも， $4 \pm 1 \%$ の範囲内にすることができた。

2）硬化コンクリートの基本的性質一一圧縮強度は, ベースコンクリート練上り時点, 流動化剂添加擋拌時 点, およびスランプ復元時点の 3 ケースについて, 標準 養生材令 1 週, 4 週強度, 打よび湿布養生材令 4 週強度 を測定した。その結果，流動化による強度の差はまった く認められなかった。また，今回床版の打設区画割りに よって生ずる橋軸直角方向の流動化コンクリートと普通 コンクリートの打継目の強度特性を確認するため, 打継 強度試験を行った。この強度試験は曲げ試験として行っ た。その試験結果によると, 流動化コンクリートによる 影響の差異は認められなかった。

\section{2 現場実験}

\section{(1) 目 的}

現場実験は，極力本施工と同一の条件（現場気象条件 等) 下で, 室内試験によって決定した配合での流動化コ ンクリートのポンパビリチーの確認, および本施工時の 打設計画の資料を得る目的で行った。

\section{（2）現場実験方法}

1） 日 時: 本施工時の 1 か月前の 7 月中旬に実施

2）実施場所 : 本施工隣接工区 (気温 $32^{\circ} \mathrm{C}$, 天候晴)
表-1 使用材料表

\begin{tabular}{|c|c|c|}
\hline 種別 & 品 & 記 \\
\hline セメント & 住友社製，普通ポルトランド & 此重 3.14 \\
\hline 細 骨 材 & $\begin{array}{l}\text { 三重県多度産細砂 (山砂) } \\
\text { 三重県木曽産粗砂 (川砂) }\end{array}$ & $\left.\begin{array}{l}\text { 比重 } 2.56 \text { (表乾), FM } 2.70 \\
\text { 比重 } 2.57 \text { (表乾), FM } 2.87\end{array}\right\}$ 山砂 $7:$ 川砂 3 \\
\hline 粗 骨 材 & 三重県木曽産砕石 & 此重 2.62 (表乾), FM 6.95, 最大寸法 $25 \mathrm{~mm}$ \\
\hline $\mathrm{AE}$ 減 水 剂 & パリック R & 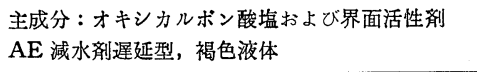 \\
\hline 流 動 化 剂 & パリック FL & $\begin{array}{l}\text { 主成分 : ナフタリンスルホン酸塩系縮合物 } \\
\text { あと添加流動化用高性能減水剤, 黑䄑色液体 }\end{array}$ \\
\hline
\end{tabular}

表一2 コンクリートの配合と比較

\begin{tabular}{|c|c|c|c|c|c|c|c|c|c|c|c|c|}
\hline & \multirow{3}{*}{$\begin{array}{c}\text { 粗骨材の } \\
\text { 最大寸法 } \\
(\mathrm{mm})\end{array}$} & \multirow{3}{*}{$\begin{array}{c}\text { スランプ } \\
\text { の 範 囲 } \\
(\%)\end{array}$} & \multirow{3}{*}{$\begin{array}{c}\text { 空気量 } \\
\text { の螌 团 } \\
(\%)\end{array}$} & \multirow{3}{*}{$\begin{array}{l}\text { 水セメン } \\
\text { 卜比 } \\
(\%)\end{array}$} & \multirow{3}{*}{$\begin{array}{c}\text { 細骨材率 } \\
(\%) \\
(\%)\end{array}$} & \multicolumn{4}{|c|}{ 単 } & \multicolumn{3}{|c|}{$\left(\mathrm{kg} / \mathrm{m}^{3}\right)$} \\
\hline & & & & & & \multirow{2}{*}{$\begin{array}{c}\text { 水 } \\
W(\mathrm{~kg})\end{array}$} & \multirow{2}{*}{$\begin{array}{l}\text { セメント } \\
C(\mathrm{~kg})\end{array}$} & \multicolumn{2}{|c|}{ 細骨材 $S(\mathrm{~kg})$} & \multirow{2}{*}{$\begin{array}{c}\text { 粗 骨材 } \\
G(\mathrm{~kg})\end{array}$} & \multicolumn{2}{|c|}{ 混 和 材 料 } \\
\hline & & & & & & & & 山 砂 & 川 砂 & & $\begin{array}{c}\text { 混 和 剂 } \\
(\mathrm{kg})\end{array}$ & $\begin{array}{c}\text { 流重化凬 } \\
(\mathrm{kg})\end{array}$ \\
\hline 通 常コンクリート & 25 & $8 \pm 2.5$ & $4 \pm 1.0$ & 50 & 40.4 & 161 & 322 & \multicolumn{2}{|c|}{$\begin{array}{c}7: 3 \\
728\end{array}$} & 1098 & 0.644 & - \\
\hline ペースコンクリート & 25 & $8 \pm 2.5$ & $4.5 \pm 1.0$ & 50 & 43.4 & 167 & 334 & \multicolumn{2}{|c|}{$\begin{array}{l}7: 3 \\
770\end{array}$} & 1027 & 0.668 & - \\
\hline 流動化コンクリート & 25 & $18 \pm 2.5$ & $4.0 \pm 1.0$ & 50 & 43.4 & 167 & 334 & \multicolumn{2}{|c|}{$\begin{array}{c}7: 3 \\
770\end{array}$} & 1027 & 0.668 & 1.67 \\
\hline
\end{tabular}


3）配合および流動化剤の添加：室内試験で決定した 配合のベースコンクリートは, 本施工時と同一の生コン 工場で製造し, アジテータ車に $4.0 \mathrm{~m}^{3}$ 積載, 現場着後 ベースコンクリートの試料を採取し，スランプを測定 後, 流動化剂を添加, 90 秒間高速擋拌して流動化コンク リートを製造した。なお，流動化後の目標スランプ值は， 室内試験では $18 \mathrm{~cm}$ で試験を行ったが，現場実験では 施工上の可能性を検討するため, $18 \mathrm{~cm}$ と $15 \mathrm{~cm}$ の 2 種類で圧送実験を行った。

4）打設設備 : コンクリートポンプ車（ダイヤクリー 卜 A-750 B）の主な仕様を 表一3 に，ポンプ車と圧送 管の配置を 図一4 に示す。また水平換算距離は，表一4 に示すように $355 \mathrm{~m}$ となった。

5） 圧送方法と供試体の採取：最初に通しモルタルを 行い, スランプ $18 \mathrm{~cm}$ の流動化コンクリート約 $2.5 \mathrm{~m}^{3}$ を低速で圧送し，管内が完全にコンクリートで充填して から再び残り $1.5 \mathrm{~m}^{8}$ を高速で圧送し，筒先で供試体を 採取した。同様にスランプ $15 \mathrm{~cm}$ の流動化コンクリー 卜を圧送した。

\section{（3）品質管理およびポンプ圧送測定}

圧送による品質変化の確認のため, 実際の筒先での試 験測定を重点的に行った。そのため品質管理測定は, ス ランプ $18 \mathrm{~cm}$ の流動化コンクリートの場合, そのベー スと, 添加後, および筒先の 3 種について, スランプ, 空気量, 温度, ブリージング, 圧縮強度 $\left(\sigma_{7}, \sigma_{28}\right)$, 乾燥 収縮を測定し, スランプ $15 \mathrm{~cm}$ の場合は, 前記の 3 種に ついてスランプ, 空気量, 温度の測定を行った。

ポンプ圧送性については，管内圧力とコンクリートの 吐出量を測定した。管内圧力を推定する方法としては, 管のひずみから管内圧力を算出する方法を用いた。

この測定は，管軸方向と管径方向の圧力は同一と仮定 し，管径方向での圧力で推定した。なお，管径方向の圧 力は, 管内圧力と, 管に発生している引張り力との釣合 いにより導いた次式による算出した。

$$
P=t / r \times E \times \varepsilon
$$

ここに, $P$ : 管径方向圧力 $\left(\mathrm{kg} / \mathrm{cm}^{2}\right)$

$$
\begin{aligned}
t & : \text { 管 厚 }(\mathrm{cm}) \\
r & : \text { 管の内半径 }(\mathrm{cm}) \\
E & : \text { 管のヤング係数 }\left(2.1 \times 10^{6} \mathrm{~kg} / \mathrm{cm}^{2}\right) \\
\varepsilon & : \text { 管のひずみ }
\end{aligned}
$$

また, ポンプ圧送性の指標には, 水平管 $1 \mathrm{~m}$ 当りの 圧力損失を用いる。圧力損失は，同一配合であってもポ ンプの吐出量によって左右される。このため, 吐出量の 測定も行った。コンクリートの吐出量については，単位 時間当りのピストンストローク数を計測し，次式を用い て吐出量を求めた。

$$
Q=\eta \times R \times V
$$

Vol. 22, No. 9, Sept. 1984

\begin{tabular}{|c|c|c|}
\hline 名 & 称 & DC A-750 B \\
\hline 最大吐出 & 量 & $75 \mathrm{~m}^{3} / \mathrm{h}$ \\
\hline 最 大 輸 & 送 & 水 平 $300 \mathrm{~m}$ (4 インチ管) \\
\hline 距 & 離 & 水 平 $440 \mathrm{~m}$ (5 インチ管) \\
\hline \multicolumn{2}{|c|}{ ンリンダ内径×メストローク長 } & $200 \mathrm{~mm} \times 1500 \mathrm{~mm}$ \\
\hline \multicolumn{2}{|c|}{ ポンプ本体最高圧力 $\times$ 最大吐出量 } & $110 \mathrm{~kg} / \mathrm{cm}^{2} \times 410 \mathrm{l} / \mathrm{min}$ \\
\hline
\end{tabular}

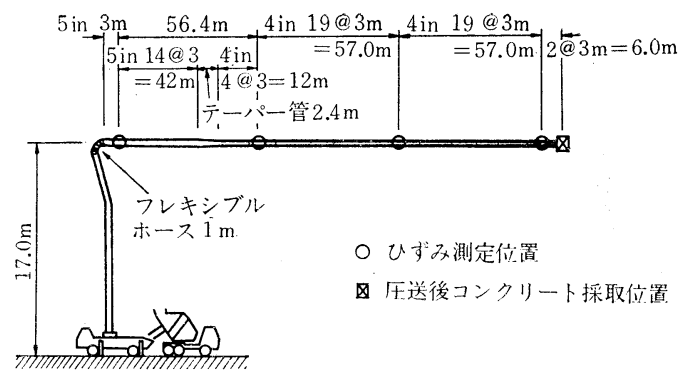

図-4 ポンプ車と圧送管の配置

\begin{tabular}{|c|c|c|c|c|}
\hline & 実長, 䉪 所 & 換 算 & 算 率 & $\begin{array}{c}\text { 水平換算延長 } \\
(\mathrm{m})\end{array}$ \\
\hline 平管 & $4+180$ & & 1 & 184 \\
\hline 直 管 & 17 & & 4 & 68 \\
\hline ペ ン ト & 9 & & 9 & 81 \\
\hline フレキンプルホース & 1 & & 6 & 6 \\
\hline テ 一 $\quad$ ハ 管 & $6^{\prime \prime} \rightarrow 5^{\prime \prime}, 5^{\prime \prime} \rightarrow 4^{\prime \prime}$ & & 8 & 16 \\
\hline 計 & & & & 355 \\
\hline
\end{tabular}

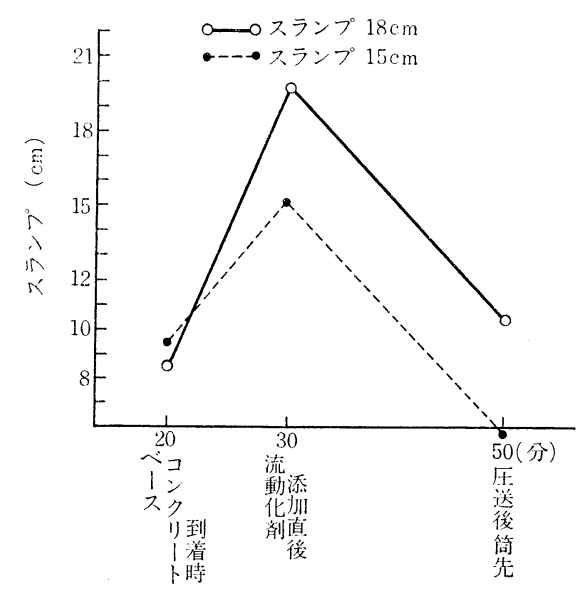

図一5 スランプの変化

表一3 ポンプ車の仕樣

表-4 水平換算延長

$$
\begin{aligned}
\text { ここに, } Q & : \text { 吐出量 }\left(\mathrm{m}^{3} / \mathrm{h}\right) \\
n & : \text { 吐出効率 }(\doteqdot 0.9) \\
V & : \text { シリンダー容積 } \\
R & : 1 \text { 時間当りのピストンストローク数 }
\end{aligned}
$$

\section{(4) 結果之考察}

1）コンクリートの品質確認：スランプについては, 図一5 に示すとおり，圧送後のスランプは $18 \mathrm{~cm}$ のも 


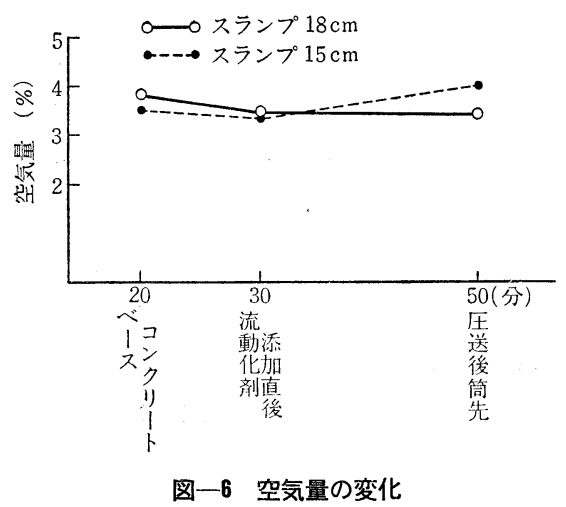

表一5 圧縮強度 $\left(\mathrm{kg} / \mathrm{cm}^{2}\right)$

\begin{tabular}{|c|c|c|c|}
\hline 試料の採取時期 & ペースコンクリート & 流動化直後 & 圧送後 \\
\hline 材 令 7 日 & 194 & 184 & 225 \\
\hline 材 令 28 日 & 268 & 266 & 308 \\
\hline \multicolumn{4}{|c|}{ 表一6 管内圧力測定結果 } \\
\hline 項 目 & 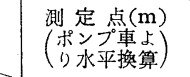 & $8 \rightarrow 18 \mathrm{~cm}$ & $8 \rightarrow 15 \mathrm{~cm}$ \\
\hline \multirow{4}{*}{ 管 内 $\begin{array}{r}\text { E: 力 } \\
\left(\mathrm{kgf} / \mathrm{cm}^{2}\right)\end{array}$} & 120 & 33.18 & 31.24 \\
\hline & 205 & 15.56 & 19.74 \\
\hline & 280 & 5.35 & 4.08 \\
\hline & 325 (筒先) & 1.26 & 1.46 \\
\hline \multirow{4}{*}{$\begin{array}{l}\text { 压 損 失 } \\
\left(\mathrm{kgf} / \mathrm{cm}^{2} / \mathrm{m}\right)\end{array}$} & $120 \sim 205$ & 0.312 & 0.204 \\
\hline & $205 \sim 280$ & 0.179 & 0.275 \\
\hline & $280 \sim 355$ & 0.072 & 0.046 \\
\hline & $205 \sim 355$ & 0.125 & 0.160 \\
\hline 吐出量 $\left(\mathrm{m}^{8} / \mathrm{h}\right)$ & & $27 \sim 28$ & $15 \sim 20$ \\
\hline \multirow{3}{*}{$\begin{array}{r}\text { コンクリート温度 } \\
\left({ }^{\circ} \mathrm{C}\right)\end{array}$} & $\therefore \quad-\pi$ & 31.0 & 31.0 \\
\hline & 流動化直後 & 31.0 & 31.5 \\
\hline & スランプ復元時 & 33.0 & 35.0 \\
\hline
\end{tabular}

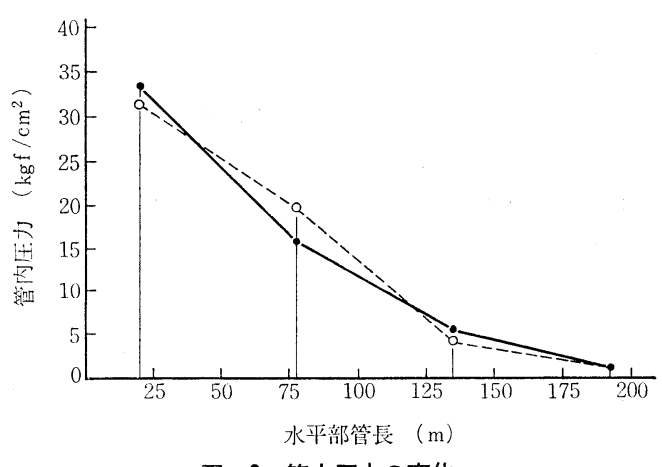

図一9 管内圧力の変化

そく寸前になり，暑中での打設は不可能と思われた。空 気量は，図一6に示すとおり目標範囲内にあるが，室内 試験と異なって添加後やや増加し, 一般的な傾向と逆の 傾向を示した。図一7 に経時変化とブリージング量を示 す。この結果をみると, 試料採取後 90 分以降, ベース コンクリートよりも流動化直後のものが大きく, 圧送後 の筒先のものがもっとも小さい傾向を示した。乾燥収縮 については図一8に示す。流動化後はベースコンクリー トより小さく, 筒先についてもベースコンクリートとほ ぼ同じ値を示した。圧縮強度を表一5 に示す。室内試験 と比較して, 発現強度はやや低い值を示したが, ベース コンクリートと流動化コンクリート，および圧送後コン クリートの差はほとんど認められなかった。

2）流動化コンクリートの圧送性：ポンパビリチーを 確認するために，スランプや空気量だけではなく，直接 管内圧力を測定することによって圧送能力を推定した。 測定結果を 表一6, 図一9 に示す。スランプ $15 \mathrm{~cm}$ のコ ンクリートでは, ポンプ油圧 $170 \mathrm{~kg} \cdot \mathrm{f} / \mathrm{cm}^{2}$ で限界に達 した。吐出量をストローク数の測定から推定すると,ス 
ランプ $18 \mathrm{~cm}$ の場合は $27 \sim 28 \mathrm{~m}^{3} / \mathrm{h}$ ，スランプ $15 \mathrm{~cm}$ の 場合 $15 \sim 20 \mathrm{~m}^{3} / \mathrm{h}$ であった。施工速度から考察すれば, まったく問題はない。

3）施工性：今回の現場実験では，生コン車の入替 え，圧送前後の試料採取，長距離圧送のための管の盛替 え作業等で圧送が再々中断したにもかかわらず，閉そく のトラブルや管の破裂等もなく圧送することができた。 しかし, 問題点として, 添加後のスランプロスの速さは 添加時のフレッシュコンクリートの品質に大きく左右さ れる。これは，前述の管の盛替え作業等に時間が制約さ れるため, コンクリートの連続圧送が非常に重要なポイ ントになってくる。このため, 適性な人員配置, すなわ ち各分野に熟練者の配置が必要となる。そして，暑中の ため，適切な配管養生と配車計画とを大念に検討して本 施工に臨んだ。

6. 流動化コンクリートの現場施工

\section{1 コンクリート打設}

\section{(1) 打設区画, 順序の決定}

打設区画については, 図一 2 に示すとおり決定した。 打設順序は，打設によるたわみおよび床版に生ずる最大 引張応力の影響の少ない側径間 $\rightarrow$ 中央径間の順とした。 施工については 3 日間に分け，そのうち 2 日間に流動化 コンクリードを使用した。

\section{（2）流動化コンクリートの製造}

ベースコンクリートの運搬には擋拌能力低下の少ない 比較的新しいアジテータ車を事前に選び， $5 \mathrm{~m}^{3}$ 積載し た。流動化剤の添加場所については, 流動化擋拌直後に 圧送できるように，アジテータ車の待機・回転場所を考 慮し，ポンプ車から約 $30 \mathrm{~m}$ 離して投入ゲートを設置し た。ゲート設置位置および投入ゲートを図一10,写真一1 に示す。流動化剂の添加量は, 圧送後の筒先における目 標スランプが $10 \mathrm{~cm}$ であるため, ベースコンクリートの スランプ実測值と施工試験よりの流動化コンクリートの スランプ $18 \mathrm{~cm}$ を確認し, 圧送後のスランプ $10 \mathrm{~cm} \mathrm{に}$ 対して変動を少なくするため,逐次,流動化剤の添加量を 調整した。そのため, 筒先, 投入ゲートおよびポンプ車の 3 地点に電話を設備し, 常時密な連絡体制を確保した。 流動化剈の添加は, ベースコンクリートのスランプを実 測確認したのち，アジテータ車がロンクリートの排出を 終了する 3 分くらい前に，ポンプオペレータから投入ゲ 一ト人電話連絡を受けて行った。とくに段取替えで配管 を切り離す時期は,アジテータ車の入替え時期と同調さ せることにより無用の排出中断が生じないよう配慮し， 流動化後, 排出完了までの時間は極力短縮した。流動化 剤添加量の計量は，投入ゲート直下に設置した液面計に よる容積計量方式の自動計量装置で行い，ホースからホ

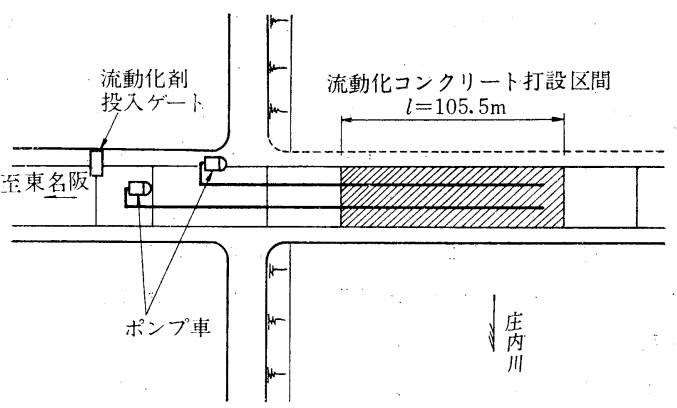

図一10 ゲート設置位置図

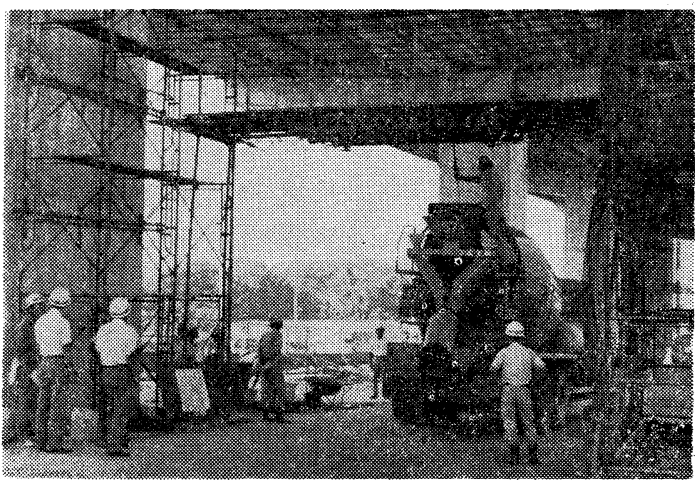

写真一1 投入ゲート

ッパー内へ添加した。装置のキャリブレーションは使用 前日に行ったが，水平に設置されていれば $3 \%$ 以内の許 容誤差を十分満足するものであった。次に，投入開始と 同時に高速擋拌を開始し, 添加完了後 2 分間の高速擋拌 を行った。擋拌時のドラム回転数は $20 \mathrm{rpm}$ 程度であっ た。擋拌中は，ゲート上部からドラム内部のスランプの 状態を目視で確認した。

\section{（3） ポンプ車，配管，およびアジテータ車の配車}

圧送には 2 台のコンクリートポンプ車を使用した。占 用帯の面積が狭いため, ポンプ車は縦列に配車し; 筒先 に近いほうのポンプ車はブームで, また他方のポンプ車 は橋脚に沿って縦配管を行った。配管については，床版 コンクリートのため筒先の移動や配管の切離しが多いの で，作業員の労働軽減のため，4インチ管とした。圧送 距離は，水平換算で最大 $360 \mathrm{~m}$, 害長 $255 \mathrm{~m}$ であった。 水平配管部は, ウレタンマットで覆い直射日光を遮断す るとともに，常時その上から散水して管およびコンクリ 一トの温度上昇を極力抑えた。またポンプ車について は, 万一の故障に備え, 同一機種のものを 2 台予備車と しで待機させた。

打設第 1 日目は，朝の通勤ラッシュの時間带を回避す るため 7 時から圧送を開始したが，次第に交通渋滞が激 しくなり，フレッシュコンクリートの品質変化のため, 流動化剤を投入しても流動化時間の延長にはならず逆に 短縮され，長距離圧送中にすでにスランプ復元をきたし 
始め, ポンプ車の圧送能力の低下がみられた。さらに生 コン排出にいっそう時間を要し，ますますスランプの復 元が進み, ついに 7 台目圧送中に管内閉そくに至った。 もちろん, 次車の待ち時間が長くなるという悪循環にも なった。そこで直ちに配管を切り離し，管内のコンクリ 一トを取り出して廃棄し, さらに待ち時間の長くなった コンクリート約 $35 \mathrm{~m}^{3}$ を廃棄処分したのち再度配管し,

新鮮なコンクリートを圧送した。

第 2 日目の打設は，第 1 日目の反省から 9 時 15 分に 圧送を開始した。第 1 日目の再圧送後および 2 日目の圧 送作業は終始順調であった。また，昼食や休㕰等による 中断は閉そくの原因となるため, 連続作業を行った。第 1 日目の圧送所要時間は 8 時間 15 分（圧送量 $185 \mathrm{~m}^{3}$ ), 第 2 日目は 5 時間 45 分 $\left(250 \mathrm{~m}^{3}\right)$ であった。打設後の 管内残留コンクリートについては，配管延長の $1 / 2$ 程度 は水洗いとし, 残り半分は配管切離し後, 人力にて取り 出した。アジテータ車の配車については, 最初の 8 台ま では, 事前の打合せにより約 7 分間隔とし，それ以後は， 圧送状況および段取替え等による中断を考慮しながら， 常時無線連絡を保ちつつ行った。そのため, アジテータ 車の現場到着後排出完了までは平均約 25 分, 出荷後排 出完了までは平均 45 分であった。

\section{(4) 施 工}

コンクリート打設前日には, 各担当の現場責任者で打 合せを行い，本施工についての主旨および各職務の責任 分担を明確化した。コンクリート打設は, ポンプ車 2 台 により左右均等に行った。締固めには, 高周波バイブレ 一タ（ $\phi 60 ）$ をポンプ車 1 台当り 2 台使用した。流動化 コンクリートの締固めは通常より容易に行えるものであ るが，横流しをしがちになるため，その防止と締固めむ らに注意し, 入念に行った。表面仕上げについては, 締 固め充填後, 木ごて, 金ごてで仕上げたのち，はけ引き を行った。ブリージングが少ないため，見掛けはり早く 仕上げをしないと時期を逸する恐れがあり注意を要し た。

\section{2 流動化コンクリートの品質管理および打設結果} 品質管理項目および頻度を 表一7に示す。試料採取時 期としては, ベースコンクリートは流動化剤添加直前, 流動化後は生コンを約 $1 \mathrm{~m}^{3}$ 排出した時点, 筒先コンタ リートでは, ポンプ車ホッパー内の吸込み口にゴムボー ル $(\phi 7 \mathrm{~cm})$ を投大し，筒先でそのボールが回収された 時点とした。ベースコンクリートの品質管理試験は生コ ン製造工場試験室の技術者が，また，流動化後および筒 先コンクリートについては流動化剤メ一カーの技術者が 主になり，おのおのコンクリート技士を中心に 6 名が 1 グループとなって行った。

スランプ, 空気量, 圧縮強度の変化を 図一11 13 に
表一7品質管理項目および頻度

\begin{tabular}{|c|c|c|c|c|}
\hline \multirow{2}{*}{ 測定項目 } & \multirow{2}{*}{ スランプ } & \multirow{2}{*}{ 空氮量 } & \multicolumn{2}{|c|}{ 圼 縮 強 度 } \\
\hline & & & 第 1 日目 & 第 2 日目 \\
\hline 流 動 化 剂 & \multirow{4}{*}{ 全車測定 } & \multirow{4}{*}{$\begin{array}{l}\text { 1 5 台目, } \\
\text { 以後 } 5 \text { 台目 } \\
\text { ごと }\end{array}$} & \multirow{4}{*}{$\begin{array}{c}1 \text { 可 } / 50 \mathrm{~m}^{3} \\
\left(\begin{array}{c}\text { 材 令 } \\
1,4,13 \text { 䓢 } \\
1,3,10 \text { 年}\end{array}\right)\end{array}$} & \multirow{4}{*}{ 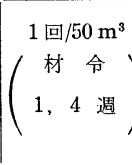 } \\
\hline 添 加 前 & & & & \\
\hline 流 動 化 後 & & & & \\
\hline 先 & & & & \\
\hline
\end{tabular}

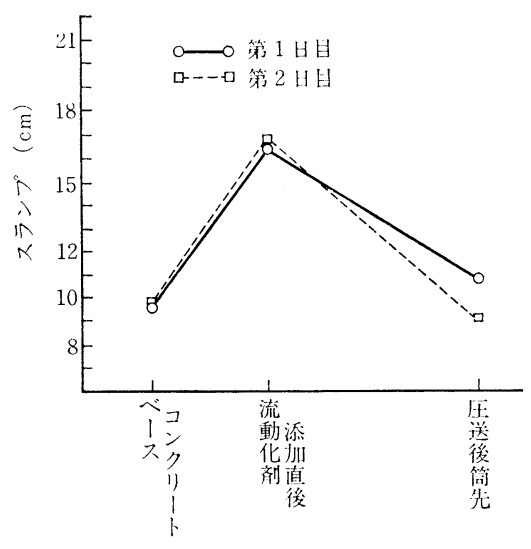

図-11 スランプの変化

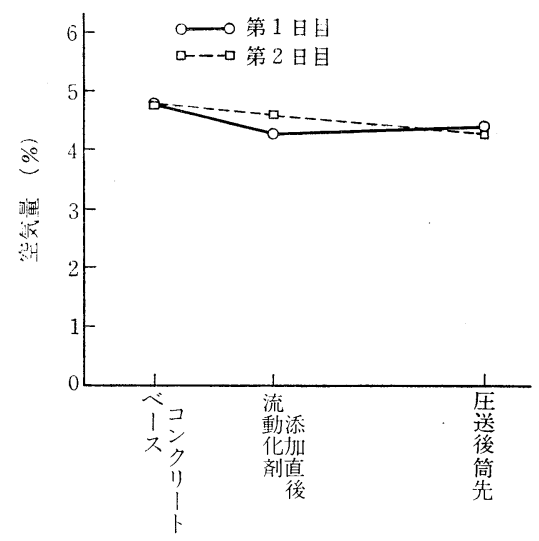

図一12 空気量の変化

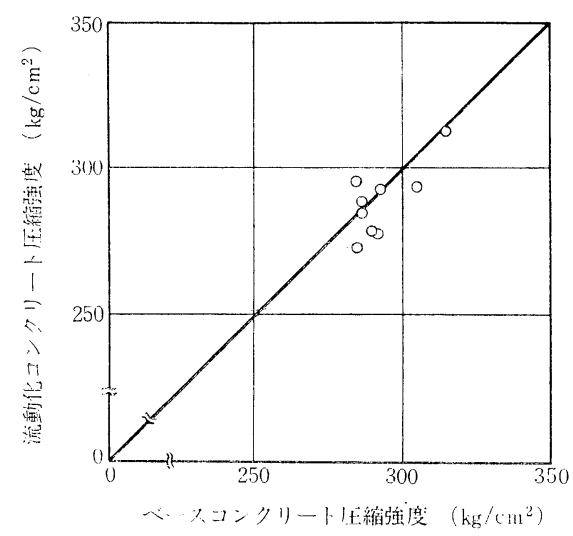

図一13圧縮強度の変化 
示す。ベースコンクリート のスランプは管理基準値 $(8 \pm 2.5 \mathrm{~cm})$ 内であったが, 筒先コンクリートでは, 閉 そく後は管理基準值 $(10 \pm$ $2.5 \mathrm{~cm}$ ) の上限值を $1 \mathrm{~cm}$ 程度超える結果となった。 これは，閉そく事故を再び 繰り返さぬよう，管理基準
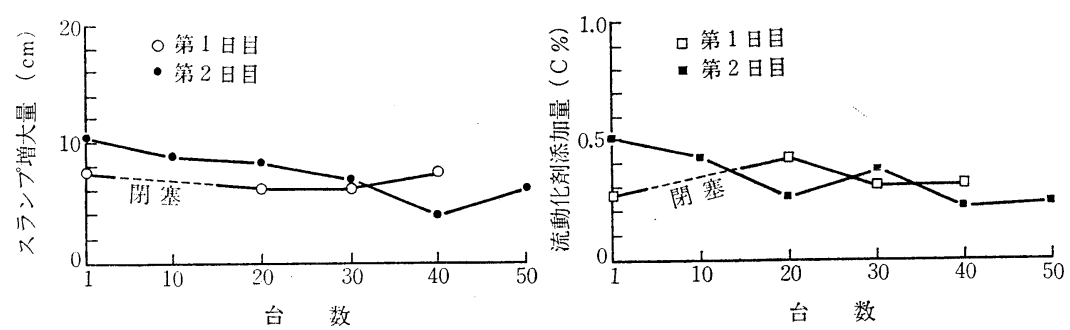

図-14 流動化剂の添加量とスランプ増大量

中においては，その傾向が顕著である。また，長距離圧 送によるスランプロスは相当大きな值となる。したがっ て, 作業が不連続とならないよう, アジテータ車の配車 計画が重要である。配車計画のポイントを列記すれば次 のとおりである。

1）運搬時間を極力短縮できるようなプラントを選定 する。

2）待ち時間を短縮するため, プラント側と出荷打合 せを十分に行い，無線等で密な連絡体制をとる。

3）流動化剤の添加は圧送排出間際に行い，投入後は 素早く排出完了する。

以上の対策を行えば, 流動化コンクリートの品質は, 通常コンクリートに比較してなんら変わるものではなか った。また, 今回の施工は暑中であったが, 今後, 暑中 においてもスランプロスの少ない流動化刘の開発が進 み, 使用実績が多くなれば，このような問題は解決され ると思われる。

最後に, 本施工にあたって, 建設省土木研究所コンク リート研究室の小林茂敏室長, 河田博之研究員にはご指 導・ご助言を賜り, また, 大獄生コン, 藤沢薬品等, 数 多くの方々の協力をいただいた。誌面を借りて感謝の意 を表す次第である。

（投稿：昭和 59 年 6 月 4 日受付）

気温 $30^{\circ} \mathrm{C}$ 以上の条件下で大きな支障もなく施工を終 えることができた。

ベースコンクリートは, フレッシュであるほど流動化 しやすく, 流動化後のスランプロスも小さい。とくに暑

《図穜案内》

（社）日本コンクリートエ学協会

回収水研究委員会報告書 (昭和 50 年 3 月)

B 5 判 163 頁 定価 3000 円 (送料 350 円)

本報告は, “生コンクリート工場における回収水（洗車およびプラントミキサの洗浄排 水から骨材分をとり去ったもの) の利用” に関する研究について, 昭和 48 年 6 月から的 1 年半にわたって実施した調査研究の経過ならびその結果の集大成である。

\section{甲申这先：(社) 日本コンクリート工学協会}

テ102 干代町区故町 5-7 TBR ビル 708 号 電話 東京 (03) 263-1571 